\title{
SPORADIC RENAL ANGIOMYOLIPOMA WITH CONCURRENT ANEURYSM FORMATION
}

\author{
Roberto Corona-Cedillo', Aime Cedillo-Pozos², \\ Jose Alberto Garcia-de la Fuente2, Juan Ignacio Stenner-Perez Gavilan3, \\ Ernesto Roldan-Valadez2,4
}

A

ngiomyolipoma is the most common mesenchymal renal neoplasm; it is observed in 0.1 to $0.22 \%$ of the general population. The classic form of angiomyolipoma has triphasic histopathologic characteristics, containing variable proportions of dysmorphic blood vessels, smooth muscle, and adipose tissue. Angiomyolipomas that usually are found in patients with tuberous sclerosis tend to bleed because of their hyper vascularity and the presence of small aneurysms. CT is the diagnostic tool of choice because of its high sensitivity for detecting fat; thin section non-contrast scans are preferable for measurement of fat density. We present the case of a 35-year-old female patient referred to the emergency room for colicky pain, with occasional irradiation to the right upper quadrant. An abdominal ultrasound was ordered under the suspicion of cholelithiasis; it revealed a mass in the upper lobe of the right kidney. A supplementary abdominal MSCT obtained in both nephrographic (80-120 secs) and excretory (3-5 mins) phase reported a hypodense mass located at the level of the upper pole of the right kidney. A renal angiogram with embolisation of the tumour and aneurysm was performed, and then the patient underwent right open radical nephrectomy. In this report, we discuss the imaging features of the angiomiolipoma as well as the two-step treatment using transarterial embolisation of the tumour and aneurysm followed by radical nephrectomy.

Keywords: angiomyolipoma, aneurysm, embolisation, kidney neoplasm, nephrectomy.

Corresponding author: Ernesto Roldan-Valadez, e-mail: ernest.roldan@usa.net

For citation: Roberto Corona-Cedillo, Aime Cedillo-Pozos, Jose Alberto Garcia-de la Fuente, Juan Ignacio Stenner-Perez Gavilan, Ernesto Roldan-Valadez. Sporadic renal angiomyolipoma with concurrent aneurysm formation. REJR 2020; 10(1):264-270.

DOI: $10.21569 / 2222-7415-2020-10-1-264-270$.

Received: $\quad$ 25.12.19 Accepted: $\quad$ 01.02.20

\section{СПОРААИЧЕСКАЯ ПОЧЕЧНАЯ АНГИОМИОАИПОМА С ВНУТРИОПУХОАЕВОЙ АНЕВРИЗМОЙ}

\author{
Роберто Корона-Седильо', Айме Седильо-Позос², \\ Хосе А^ьберто Гарсиа-Ае-^а-Фуэнте2, \\ Хуан Игнасио Стеннер-Перес Гави^ан ${ }^{3}$, Эрнесто РолАан-Валалес 2,4
}

нгиомиолипома явцяется наиболее распространенным мезенхимальным новообразованием почек и наблюдается в $0,1 \%-0,22 \%$ от общей численности насемения. Классическая форма ангиомиолипомы имеет трехфазные гистопатологические характеристики, содержащие различные пропорции дисморфных кровеносных сосудов, гладких мышц и жировой ткани. Ангиомиолипомы которые обычно встречаются у пациентов с туберозным склерозом, часто кровоточат из-за гиперваскуляризации и наличия небольших аневризм. Компьютерная томография является "золотым" стандартом в диагностике данной патологии в виду высокой чувствительности метода.

Представляем клинический случай 35-летней пациентки, которая обратилась в

1 - Department of Radiology, Medica Sur Clinic and Foundation.

Mexico City. Mexico. 2 - Directorate of Research, Hospital General de Mexico "Dr Eduardo Liceaga".

Mexico City, Mexico.

3 - Department of Urology, Medica Sur Clinic and Foundation, Department of Radiology, Hospital General de Mexico "Dr Eduardo Liceaga", Mexico City, Mexico. 4 - I.M. Sechenov First Moscow State Medical University (Sechenov University). Moscow, Russia.

1 - Отделение радиологии, клиника Medica Sur и фонд. Мехико. Мексика. 2 - Больница общего профиля Мексики "Доктор Эдуардо Аицеага".

Мехико, Мексика.

3 - Отделение урологии, клиника и фонд Medica Sur, отделение радиологии, больница общего профияя в Мехико "Доктор Эдуардо Аицеага".

Мехико, Мексика.

4 - Сеченовский Уни-

верситет.

Москва, Россия. 
отделение неотложной помощи по поводу болей в эпигастральной области. УЗИ брюшной полости было проведено при подозрении на желчнокаменную болезнь, при этом в верхней доле правой почки бымо выявлено образование. По даным МСКТ брюшной помости в нефрографическую (80-120 сек) и в экскреторную (3-5 мин) фазы выявлено гиподенсное образвание, расположенное на уровне верхнего полюса правой почки. Была выполнена селективная ангиография с эмболизацией опухоли и аневризмы с последующей правосторонней радикальной нефрэктомией. В этом наблюдении представлены особенности визуализации ангиомиолипом, а также возможности мечения с использованием трансартериальной эмболизации опухоли и аневризмы с последующей радикальной нефрэктомией.

К^ючевые слова: ангиомиолипома, аневризма, эмболизация, новообразования почек, нефрэктомия.

Контактный автор: Эрнесто Роланд-Валадез, e-mail: ernest.roldan@usa.net

Для иитирования: Роберто Корона-Седильо, Айме Седильо-Позос, Хосе Альберто Гарсиа-де-ла-Фуэнте, Хуан Игнасио Стеннер-Перес Гавилан, Эрнесто Ролдан-Валадес. Спорадическая почечная ангиомиолипома $c$ внутриопухолевой аневризмой. REJR 2020; 10(1):264-270. DOI:10.21569/2222-7415-2020-10-1-264-270.

Статья получена: $\quad 25.12 .19 \quad$ Статья принята: $\quad \mathbf{0 1 . 0 2 . 2 0}$

I

\section{ntroduction.}

Angiomyolipoma is the most common mesenchymal renal neoplasm; it is observed in 0.1 to $0.22 \%$ of the general population and is four times more common in female [1]. The classic angiomyolipoma has triphasic histopathologic characteristics, containing variable proportions of dysmorphic blood vessels, smooth muscle, and adipose tissue [2]. Two types have been described: sporadic angiomyolipoma and angiomyolipoma associated with tuberous sclerosis, these types reveal a distinctly different pathology and imaging appearance, and in some cases, a distinct clinical behaviour which determines the treatment (Table 1) [3]. Angiomyolipomas in patients with tuberous sclerosis tend to bleed because of their hypervascularity and the presence of small aneurysms. Macroaneurysms, are rarely seen in imaging of these patients [4].

Angiomyolipomas may present as a welldefined focal and infiltrative mass or as a pedunculated mass [5]. Angiomyolipomas, more than 4 $\mathrm{cm}$ in diameter, require treatment because of the risk of bleeding [6]. CT is the diagnostic tool of choice because of its high sensitivity detecting fat; thin section non-contrast scans are preferable for measurement of fat density [6]. AML appears hyperechoic on sonography equal to renal sinus fat or producing negatively attenuating areas on $\mathrm{CT}$ or $\mathrm{T} 1$ hyperintensity with signal loss on fatsaturated sequences on MR imaging [7,8]. With the intent of early curative surgery for a presumed renal cell carcinoma, many renal masses are resected at surgery without a confirmed diagnosis. Many of them are benign, and some are angio- myolipomas. The determination of renal angiomyolipoma using imaging is, therefore, as important as ever [3]. Surgery is the best treatment for these cases because of the risk of severe bleeding following aneurysmal rupture [5]. This report describes an unusual clinic presentation of renal angiomyolipoma with an aneurysm found in a 3D CT reconstruction in a 35-year-old female.

Case report.

A 35-year-old female was referred from the emergency room with colicky pain, predominantly in the epigastrium, intermittent, without triggers, with occasional irradiation to the right upper quadrant and sometimes bilateral lumbar pain, which decreased partially with the use of oral analgesics. Later, the patient presented an episode of severe pain accompanied by diaphoresis and fainting, reaching syncope.

The patient referred non-quantified weight loss in the last three months and progressive fatigue. Blood studies were unremarkable, hematuria was observed in the urinalysis, with preserved renal function. An abdominal ultrasound was ordered, and it revealed a mass in the upper lobe of the right kidney. A supplementary abdominal CT obtained in both nephrographic (80-120 secs) and excretory (3-5 mins) phase reported: right kidney in a usual situation with dimensions $11.3 \times 4.8 \times 4.8$ $\mathrm{cm}$; a hypodense mass was observed in the parenchyma with a hypodense centre located at the level of the upper pole of right kidney, measuring $8.4 \times 6.1 \times 7.0 \mathrm{~cm}$. In the non-contrasted phase, mass density was between -71 to 23 Hounsfield 
Table №1. Classification and clinical features of renal angiomyolipoma.

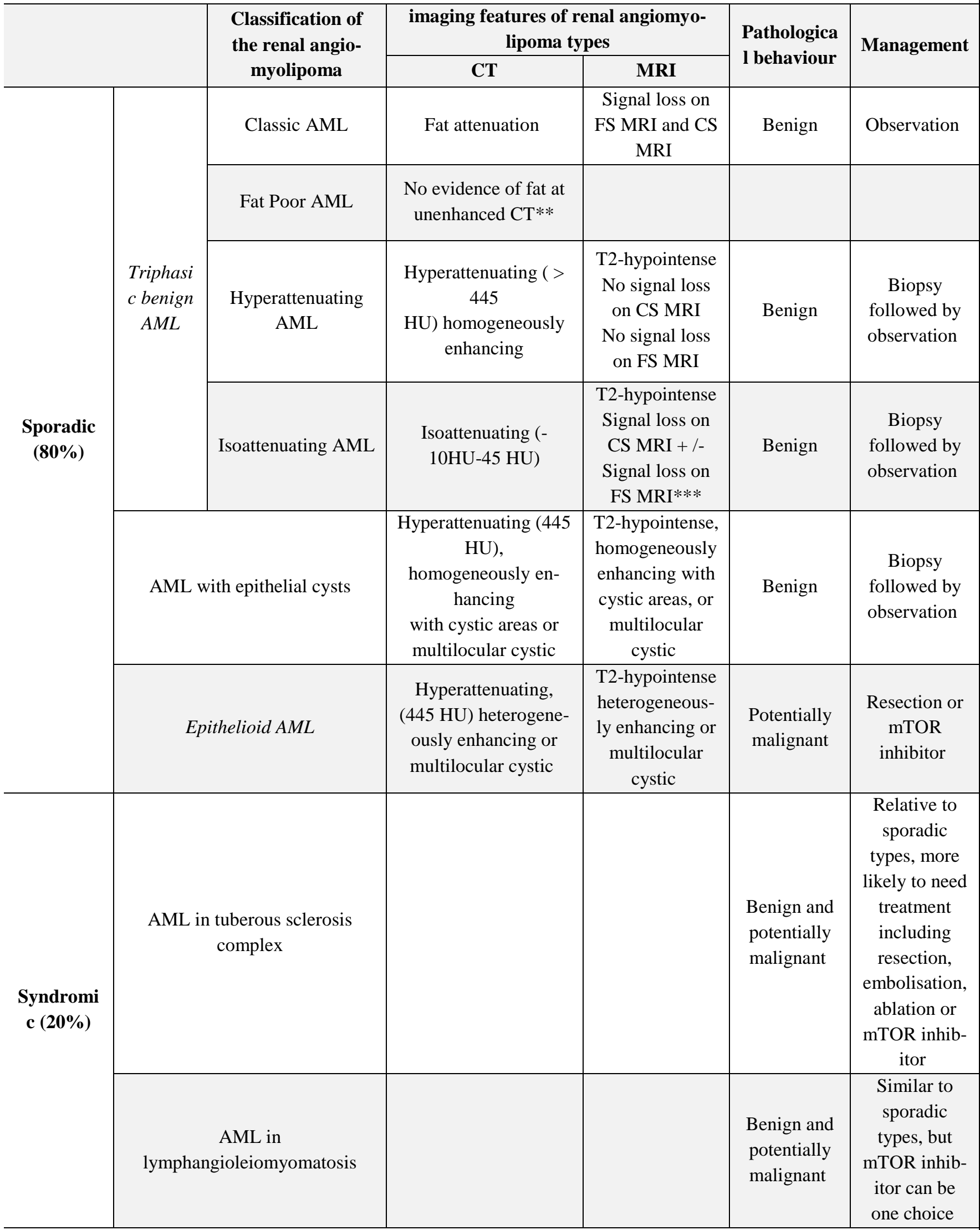

AML: angiomyolipomas; FS: frequency-selective fat suppression; CS: chemical shift; mTOR (mammalian target of rapamycin). Attenuation values are approximations.

**When thin (1.5-3 mm) sections are used; ***Signal loss on FS MRI may or may not be present. 


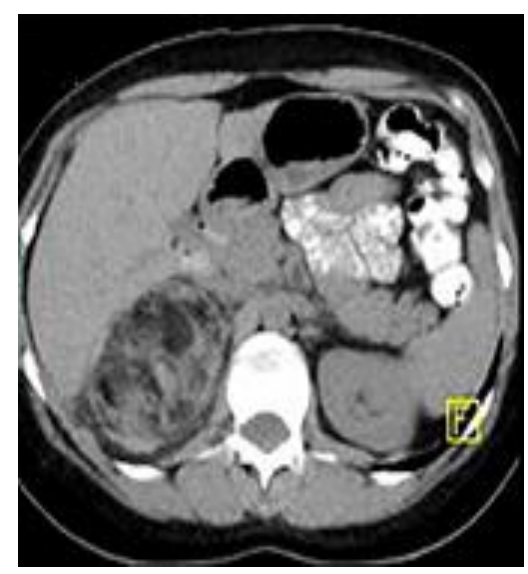

Fig. 1 a (Рис. 1 a)

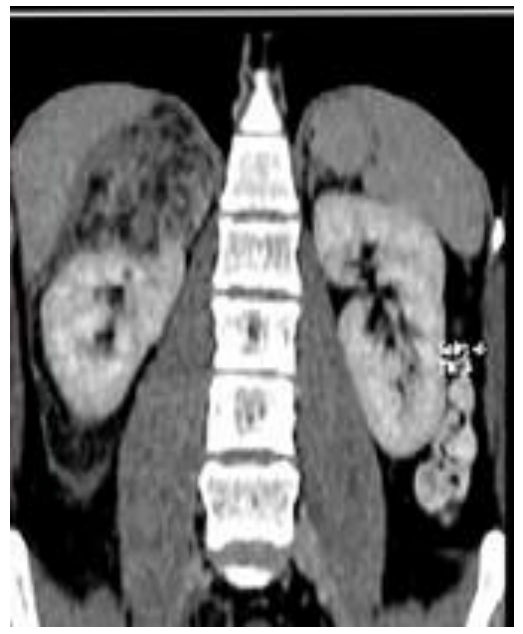

Fig. 1 d (Рис. 1 r)

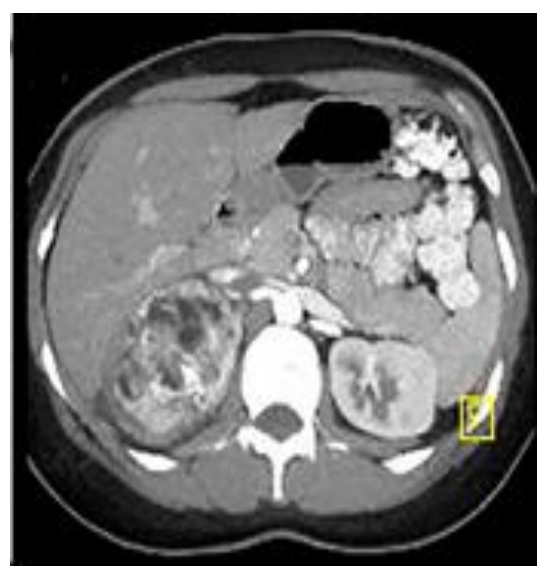

Fig. 1 b (Pис. 1 б)

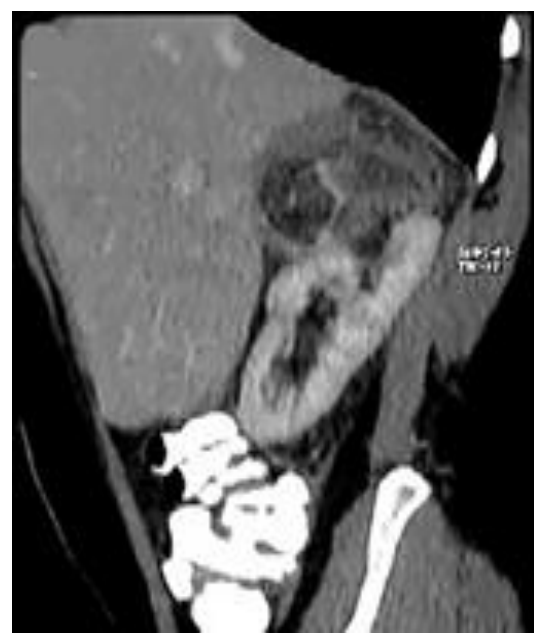

Fig. 1 e (Рис. 1 A)

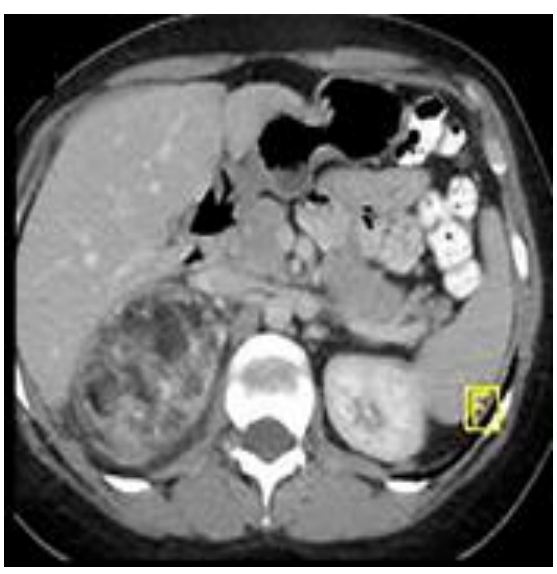

Fig. 1 с (Pис. 1 в)

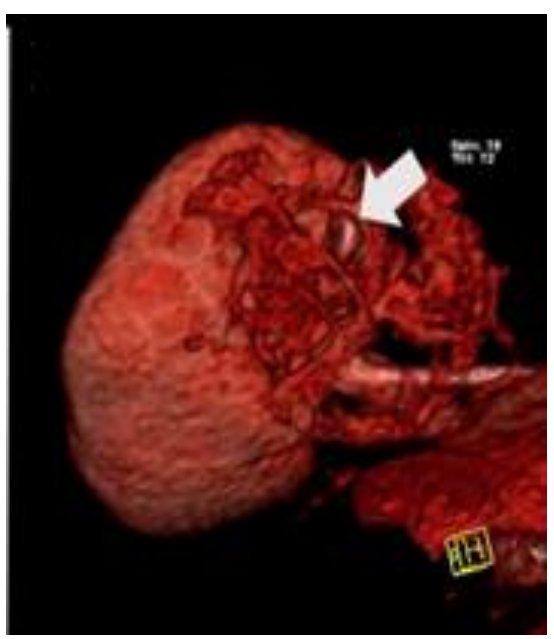

Fig. $1 \mathrm{f}$ (Рис. $1 \mathrm{e})$

Fig. 1. MSCT. A 35 years old female, renal angiomyolipoma.

A, B, C - axial CT views during the non-contrast, nephrographic and excretory phases respectively, revealing a heterogeneous, predominantly hypodense mass located at the level of the upper pole of right kidney.

D, E - coronal and sagittal views with contrast enhancement depicting the renal mass in the upper pole of the right kidney.

F - 3D reconstruction where it is possible to identify the presence of a renal aneurysm (white arrow).

\section{Рис. 1. МСКт. Женщина 35 лет, почечная ангиомиолипома.}

А, Б, В - аксиальные реконструкции, нативная, нефрографическая и экскреторная фазы. Определяется гетерогенное, преимущественно гиподенсное образование, расположенное на уровне верхнего полюса правой почки.

Г, Д - корональная и сагиттальная рконструкции, с контрастным усилением. Определяется образование верхнего полюса почки.

E - 3D реконструкция. Аневризма почки (белая стрелка). 


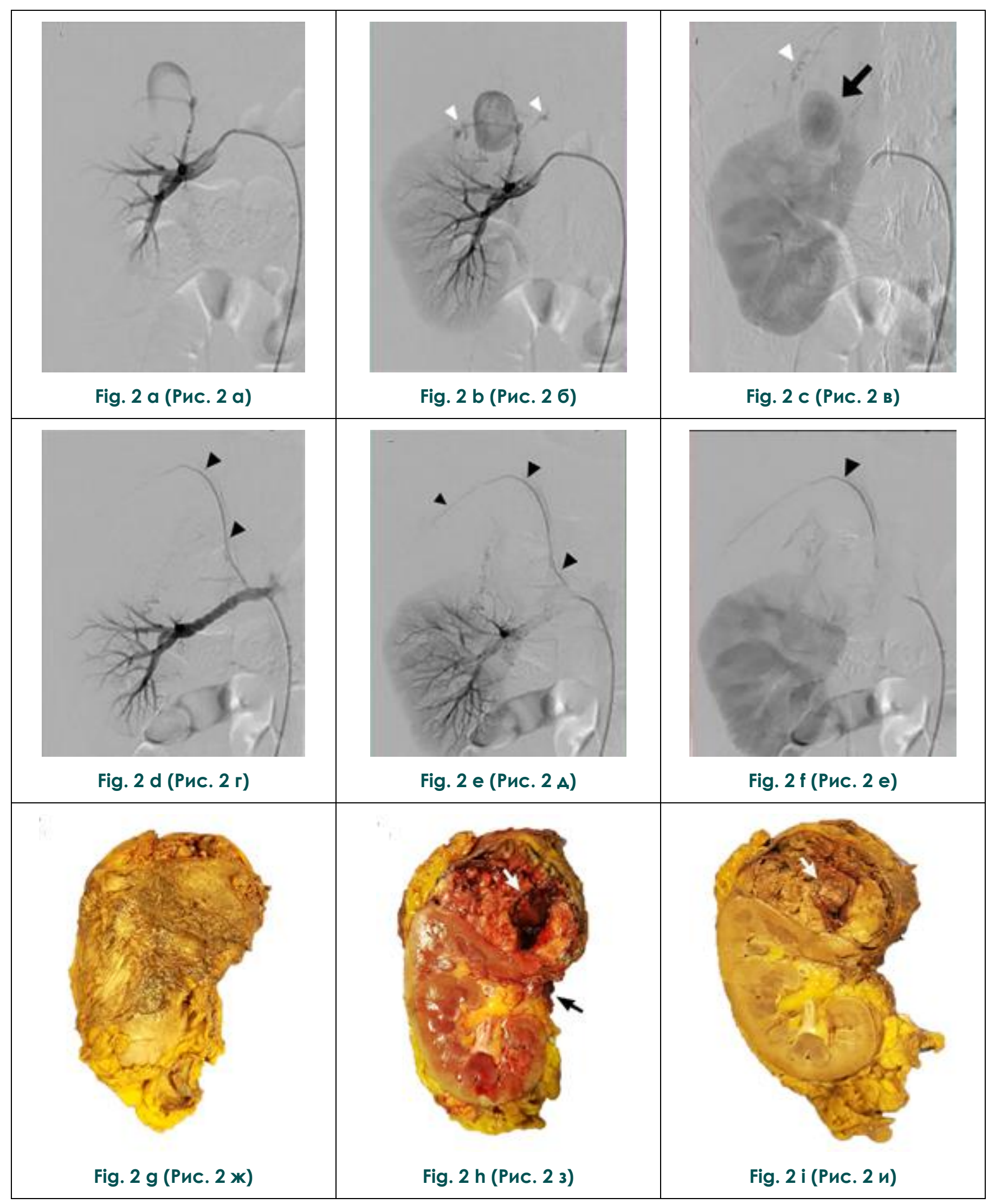




\section{Fig. 2. Angiography (A-F), gross specimen (G-I). Renal angiomyolipoma, A 35 years old female.}

A-F - selective injection into the right-renal artery to visualise de angiomyolipoma and aneurysm.

A, B, C - show the gradual filling of the vascularity of the right kidney and the aneurysm inside the tumour; the mass is located in the upper pole of the kidney (black arrow) there are small intratumoral vessels (white arrowheads).

$\mathrm{D}, \mathrm{E}, \mathrm{F}$ - images after endovascular treatment demonstrating the absence of filling in the aneurysm and tumoral vessels with preservation of the middle and lower poles of the kidney; black arrowheads point the vascular contour of the tumoral mass.

G-I - excised right kidney.

$\mathrm{G}$ - external view after the radical nephrectomy showing preservation of the renal capsule.

$\mathrm{H}, \mathrm{I}$ - internal view after sagittal cut of the kidney revealing the tumoral mass with the presence of a non-ruptured aneurysm (white arrow), it is possible to see the limits of the tumoral mass and the normal parenchyma with sparing of the inferior vena cava (black arrow).

\section{Рис. 2. Ангиограмма (А-Е), макропрепарат (Ж-И). Ангиомиолипома почки, женщина 35 лет.}

А-Е - селективная ангиография правой почечной артерии для визуализации ангиомиолипомы и аневризмы.

А, Б, В - постепенное заполнение сосудистой системы правой почки и аневризмы внутри опухоли; образование расположено в верхнем полюсе почки (черная стрелка), имеются небольшие внутриопухолевые сосуды (белые стрелки).

Г, Д, Е - изображения после эндоваскулярного мечения, демонстрирующие отсутствие заполнения аневризмы и опухолевых сосудов с сохранением среднего и нижнего полюсов почки; черные стрелки указывают на сосудистый контур опухолевой массы.

Ж-И - макропрепарат правой почки.

Ж - состояние после радикальной нефрэктомии, показывающий сохранение почечной капсулы.

3, И - внутренний вид после сагиттального разреза почки, выявляющий опухолевую массу с наличием неразорвавшейся аневризмы (белая стрелка), визуализируются границы опухолевой массы и нормальной паренхимы почки с сохранением нижней части полой вены (черная стрелка).

units; it was associated with a heterogeneous pattern of infiltration fat. In the retrospective evaluation of the $3 \mathrm{D}$ reconstruction of the $\mathrm{CT}$, an image suggestive of the aneurysm was observed (Fig. 1AF). A selective right-renal angiogram with embolisation of the tumour and aneurysm was performed (Fig. 2A-F). Based on the clinical and radiologic findings, a presumptive diagnosis of AML and an aneurysm of the right kidney was made.

A right radical nephrectomy using transperitoneal approach was performed with the following findings: adrenal gland with a mass adhered to the upper pole of right kidney and liver (Fig. 2G-I); histopathology examination confirmed the diagnosis of AML. The post-surgical period was uneventful with preserved renal function, but haemoglobin of $7.9 \mathrm{mg} / \mathrm{dl}$ was identified, and the patient received a transfusion of a packed red cell with no complications. The patient was discharged five days after surgery with routine immediate postsurgical follow-up.

Discussion.

Angiomyolipoma is the most common mes- enchymal renal neoplasm, is observed in 0.1 to $0.22 \%$ of the general population and is four times more common in female, they are commonly found in the kidney in clinical practice [1].

We consider this report relevant contemplating four elements. First, the clinical presentation is unusual as most of the patient's debut with flank pain and hematuria; in our case, it was associated with diaphoresis, fainting and syncope also the patient referred a non-quantified weight loss with progressive fatigue, which are not typical symptoms of sporadic AML.

Second, although CT is the investigation of choice because of its high sensitivity for detecting fat; usually, most aneurysms are invisible on contrast-enhanced CT, and aneurysm (as described in the present case) is not common [4, 6]. It was possible to observe the intratumoral aneurysm in the 3D- CT reconstruction.

Third, we did not expect an aneurysm because it is associated with tuberous sclerosis and the patient did not show evidence of this diagnosis. The aneurysm found in this patient had 28 $\mathrm{mm}$ of a diameter which was above the 95 percen- 


\section{RUSSIAN ELECTRONIC JOURNAL OF RADIOLOGY}

tile reported by Yamakado et al. [9]. He found that in patients with angiomyolipoma, aneurysms with a mean size of $13.3 \mathrm{~mm} \pm 6.2 \mathrm{~mm}$ belonged to the group of increased risk ruptured aneurysm which contrasts with aneurysms with a mean of $2.4 \mathrm{~mm}$ $\pm 2.9 \mathrm{~mm}$ that corresponded to the unruptured group. Angiomyolipomas $\geq 4 \mathrm{~cm}$ and aneurysms $\geq$ $5 \mathrm{~mm}$ have been used as predictors of rupture; with a sensitivity and specificity of $100 \%$ and $38 \%$ respectively [9].

Fourth, the two-step treatment, in this case, transarterial embolisation of the tumour and aneurysm followed by nephrectomy has been reported scarcely in the literature [10]. Although some authors like Oesterling et al. recommended that symptomatic tumours larger than $4 \mathrm{~cm}$ were treated by selective angiographic embolisation or partial nephrectomy; for this case we perform embolisation of the angiomyolipoma and the aneurysm before radical nephrectomy as a way to reduce tumour size, and decrease the risk of bleed-

\section{References:}

1. Fujii $Y$, Komai $Y$, Saito $K$, et al. Incidence of benign pathologic lesions at partial nephrectomy for presumed RCC renal masses: Japanese dual-center experience with 176 consecutive patients. Urology. $2008 \quad$ Sep;72(3):598-602. doi: 10.1016/j.urology.2008.04.054. PubMed PMID: 18649929.

2. Froemming AT, Boland J, Cheville J, et al. Renal epithelioid angiomyolipoma: imaging characteristics in nine cases with radiologic-pathologic correlation and review of the literature. AJR Am J Roentgenol. 2013 Feb;200(2):W178-86. doi: 10.2214/AJR.12.8776. PubMed PMID: 23345382.

3. Jinzaki M, Silverman SG, Akita H, et al. Diagnosis of Renal Angiomyolipomas: Classic, Fat-Poor, and Epithelioid Types. Semin Ultrasound CT MR. 2017 Feb;38(1):37-46. doi: 10.1053/j.sult.2016.11.001. PubMed PMID: 28237279.

4. Choh NA, Choh SA, Yousuf R, et al. A giant aneurysm arising from renal angiomyolipoma in tuberous sclerosis. Arch Dis Child. 2009 Jan;94(1):47-8. doi: 10.1136/adc.2008.143610. PubMed PMID: 19103788.

5. Choh NA, Choh SA, Yousuf R, et al. A giant aneurysm arising from renal angiomyolipoma in tuberous sclerosis. Archives of Disease in Childhood. 2009;94(1):47-48. doi: 10.1136/adc.2008.143610.

6. Casper KA DL, Chen B, et al. Tuberous sclerosis complex: renal imaging findings. Radiology. 2002;225:451-6.

7. Patil AR, Chandra R, Gupta A, et al. Giant aneurysm for- ing and rupture $[11,12]$. Previous reports have revealed how prophylactic embolisation decrease tumour size; this procedure is recommended in high-risk patients with symptomatic tumours, patients with difficult follow up and in women who are planning future pregnancy [13].

\section{Conclusion.}

The evaluation of renal masses using CT, 3D reconstruction might help in the visualisation of intratumoral aneurysms. In the suspicion of an AML, clinicians should discard the presence of tuberous sclerosis. Two measures are essential to remember: tumour size $\geq 4 \mathrm{~cm}$ and aneurysm size $\geq 5 \mathrm{~mm}$, as they are predictors of rupture. When nephrectomy is not performed, transarterial embolisation is followed by serial CT or ultrasound during at least one year. mation in sporadic renal angiomyolipoma. J Radiol Case Rep. 2010;4(6):21-7. doi: 10.3941/jrcr.v4i6.439. PubMed PMID: 22470737; PubMed Central PMCID: PMCPMC3303414.

8. Zeev V. Maizlin M, Paul Gottlieb, MD,, Yehudit Corat-Simon M, Simon Strauss, MB, ChB. Various Appearances of Multiple Angiomyolipomas in the Same Kidney in a Patient Without Tuberous Sclerosis. J Ultrasound Med. 2002;21:211-213.

9. Yamakado K, Tanaka N, Nakagawa T, et al. Renal angiomyolipoma: relationships between tumor size, aneurysm formation, and rupture. Radiology. 2002 Oct;225(1):78-82. doi: 10.1148/radiol.2251011477. PubMed PMID: 12354988.

10. Kennelly MJ, Grossman HB, Cho KJ. Outcome analysis of 42 cases of renal angiomyolipoma. J Urol. 1994 Dec;152/6 Pt 1):1988-91. PubMed PMID: 7966657.

11. Oesterling JE, Fishman EK, Goldman SM, et al. The management of renal angiomyolipoma. J Urol. 1986 Jun;135(6):1121-4. PubMed PMID: 3520013.

12. Kapanadze L.B., Novikov A.A. MSCT in the diagnosis of benign tumors of the kidney (oncocytoma). REJR. 2014; 4 (3): 81-85.

13. Nelson CP, Sanda MG. Contemporary diagnosis and management of renal angiomyolipoma. J Urol. 2002 Oct;168(4 Pt 1):1315-25. doi: 10.1097/01.ju.0000028200.86216.b2. PubMed PMID: 12352384. 